\title{
PROJETOS DE FORMAÇÃO HUMANA EUGENISTA E HIGIENISTA: PRESCRIÇÕES PARA A EDUCAÇÃO FÍSICA EM PERIÓDICOS (1932-1960)
}

\author{
JULIANA MARTINS CASSANI ${ }^{1}$ \\ ORCID: https://orcid.org/0000-0001-6332-7930 \\ AMARÍLIO FERREIRA NETO² \\ ORCID: https://orcid.org/0000-0002-3624-4352 \\ WAGNER DOS SANTOS \\ ORCID: https://orcid.org/0000-0002-9216-7291
}

\begin{abstract}
RESUMO: $O$ artigo objetiva compreender as orientações para o ensino da Educação Física, fundamentadas nos projetos de formação humana eugenista e higienista. Possui, como fontes, a Revista de Educação Física (230 matérias) e a Revista Educação Physica (405 matérias). Utiliza, como pressupostos teóricos, os conceitos de análise pela materialidade e práticas de apropriaçôes. Os resultados sinalizam que o diálogo dos articulistas com os princípios da eugenia e do higienismo estava relacionado com os perfis editoriais das revistas, em um cenário de negociações em relação às perspectivas de formação assumidas por eles. Esse teorizar conferiu cientificidade à Educação Física e ofereceu as bases para a publicação de prescrições que orientassem a formação e a prática docente. Nas fontes, teoria e prática imbricavam-se, conformando as revistas como dispositivos de uso didáticopedagógico e contribuindo com a inserção e a consolidação da Educação Física nos currículos escolares.
\end{abstract}

Palavras-chave: Educação Física, eugenia, higienismo, revista, prescrições.

\section{EUGENIST AND SOCIAL HYGIENE HUMAN FORMATION PROJECTS: PRESCRIPTIONS FOR PHYSICAL EDUCATION IN MAGAZINES (1932-1960)}

\footnotetext{
ABSTRACT: The article aims to understand the guidelines for Physical Education teaching based on eugenicist and social hygiene training projects. We used as sources the Revista Educação Física (230 articles) and Revista Educação Physica (405 articles). The concepts of materiality analysis and appropriation practices are used as theoretical assumptions. The results indicate that the writers' dialogue with the

${ }^{1}$ Programa de Pós-Graduação em Ciências, Tecnologia e Educação (Mestrado Profissional), Faculdade Vale do Cricaré. São Mateus, ES, Brasil. <julianacassani@gmail.com>

${ }^{2}$ Programa de Pós-Graduação em Educação Física, Universidade Federal do Espírito Santo (UFES). Vitória, ES, Brasil. <amariliovix@gmail.com>

${ }^{3}$ Programas de Pós-Graduação em Educação e Educação Física, Universidade Federal do Espírito Santo (UFES). Vitória, ES, Brasil.<wagnercefd@gmail.com>
} 
principles of eugenics and social hygiene was related to the editorial profiles of the magazines, in a negotiation scenario related to the formation perspectives assumed by them. This theorizing conferred scientificity to Physical Education and supported the publication of prescriptions that would guide training and teaching practice. In the sources, theory and practice were intertwined, thus, the magazines are didactic-pedagogical devices, contributing to the insertion and consolidation of Physical Education in school curriculum.

Keywords: Physical Education, eugenics, hygiene, magazine, prescriptions.

\section{PROYECTOS DE FORMACIÓN HUMANA EUGENISTA E HIGIENISTA: PRESCRIPCIONES PARA LA EDUCACIÓN FÍSICA EN PUBLICACIONES PERIÓDICAS (1932-1960)}

RESÚMEN: El artículo busca comprender las orientaciones para la enseñanza de la Educación Física, basadas en proyectos de formación humana eugenistas e higienistas. Tiene, como fuentes, la Revista de Educação Física (230 artículos) y la Revista Educação Physica (405 artículos). Utiliza, como supuestos teóricos, los conceptos de análisis por la materialidad y prácticas de apropiación. Los resultados indican que el diálogo de los articulistas con los principios de eugenesia e higienismo estuvo relacionado a los perfiles editoriales de las revistas, en un escenario de negociaciones con relación a las perspectivas de formación asumidas por ellos. Esta teorización confirió cientificidad a la Educación Física y ofreció la base para la publicación de prescripciones que orientaran la formación y la práctica docente. En las fuentes, la teoría y la práctica estaban entrelazadas, configurando las revistas como dispositivos didácticos y pedagógicos y contribuyendo con la inserción y consolidación de la Educación Física en los currículos escolares.

Palabras clave: Educación Física, eugenesia, higienismo, revista, prescripciones.

\section{INTRODUÇÃO}

O campo da historiografia da Educação tem demonstrado um contínuo interesse em analisar a circulação de teorias que, no fim do século XIX e início do século XX, ofereciam as bases para o debate sobre raça, higiene e saúde no Brasil. Essas pesquisas entendem que a importância apresentada à época sobre a construção de uma nação sadia de corpo e de espírito requeria práticas educativas fundamentadas nesses projetos de formação humana (CARVALHO, 1998; GONDRA, 2004; STEPHANOU, 2005; GUALTIERI, 2008; LORENZ; VECHIA, 2009).

No cenário político, os intelectuais empenhavam-se em produzir discursos sobre o perfil ideal do povo brasileiro, de tal modo que pudessem transformar e inserir o País na modernidade. Pautados nos avanços da ciência, sobretudo da Biologia e da Medicina, educadores e médicos viam-se responsáveis por fazer a sociedade avançar, com a crença de que teriam todas as ferramentas para tal. Sob os princípios da eugenia, afirmavam que a miscigenação racial comprometeria as futuras gerações, requerendo intervenções de natureza biológica; aqueles que buscavam medidas no campo da higiene, por seu turno, sinalizavam a necessidade de melhoria das questões sociais (pobreza, desnutrição, propagação de doenças e analfabetismo) para o reconhecimento do Brasil como um país moderno (GUALTIERI, 2008; GÓIS JÚNIOR; GARCIA, 2011; GÓIS JÚNIOR, 2013; SOUZA, 2016).

No âmbito da literatura, os intelectuais também criavam identidades nacionais para o Brasil, a fim de gerar, no imaginário social da população, diferentes símbolos que "representassem" o homem típico brasileiro. José de Alencar consagrou a figura do índio como um emblema nacional; Euclides da Cunha, em 1905, destacou a força e as fraquezas do sertanejo; já Monteiro Lobato, em 1918, construiu a figura simbólica do Jeca Tatu, um trabalhador rural do interior de São Paulo (SP), considerado uma espécie em degeneração por sua origem "mestiça" (LORENZ; VECHIA, 2009).

A referida personagem foi associada à ausência de higiene, à aversão ao trabalho, ao desinteresse pela cultura letrada, sendo rodeada por moléstias e taras. Era preciso, em favor do desenvolvimento de uma sociedade moderna, urbana e industrial, que se pretendia em meados da 
década de 1930, substituir aquela imagem do brasileiro por uma que almejasse o progresso do País e para isso contribuísse (LORENZ; VECHIA, 2009).

Ao reconhecermos que, no Brasil, as teorias da eugenia e da higiene foram produzidas com ênfases e intencionalidades diversas, assumimos, como objetivo deste artigo, compreender as orientações para o ensino da Educação Física (EF) fundamentadas nos projetos de formação humana eugenista e higienista, veiculadas na imprensa periódica de ensino e de técnicas (1932-1960). Uma vez que se configura como desdobramento da tese de Cassani (2018), a pesquisa compreende esses impressos como dispositivos de uso didático-pedagógico que prescreviam e orientavam a formação e a prática do professorado, cuja finalidade era contribuir com a inserção e a consolidação da EF no processo de escolarização. ${ }^{4}$

De acordo com Ferreira Neto (2005) e Ferreira Neto et al. (2014), esses periódicos constituem um conjunto de suportes materiais editados no formato de revistas, livros e A4, postos em circulação a partir da década de 1930. Eles foram produzidos com o propósito de lutar por formação profissional, propagar legislações específicas para a atuação docente e veicular métodos ginásticos e práticas que conferissem uniformidade à EF. Para difundi-la, seja para o trabalho na escola, seja em outros espaços, os editores divulgavam matérias sobre instalações, materiais, noticiários e detalhamentos técnicos dos diferentes tipos de exercícios e esportes.

Para fins desta pesquisa, serão analisadas as publicações da Revista de Educação Física (REF) e da Revista Educação Physica (REPhy), ambas criadas em 1932. A REF, chancelada pela Escola de Educação Física do Exército (EsEFEx), buscava propagar orientações para o ensino da EF fundamentadas nos princípios pedagógicos da Instituição. Por sua vez, a REPhy foi organizada por intelectuais civis e publicada pela Companhia Brasil Editora S.A., entidade de caráter privado e comercial. O objetivo da revista era difundir os fundamentos científicos da EF e os programas de exercícios a serem aplicados nas instituições escolares, constituindo-se como referência no Brasil e em outros países (REVISTA TÉCNICA, REPHy, 1932, s. p.).

\section{TEORIA E MÉTODO}

Tomamos como referência os estudos de Roger Chartier (2002) sobre a análise dos impressos como fontes e objetos. Sob essa perspectiva, consideramos os periódicos como produto das relações entre diferentes autores e editores, compreendendo-os como objetos culturais, por meio dos quais saberes, modelos e formas de pensar são colocados à leitura. Focalizamos os múltiplos dispositivos produzidos estrategicamente pelos articulistas a fim de "induzir" à leitura do impresso, pois "[...] não há texto fora do suporte que o dá a ler, e sublinhar o fato de que não existe a compreensão de um texto, [...] que não dependa das formas através das quais ele atinge o leitor" (CHARTIER, 2002, p. 127).

Em apropriação a Anne-Marie Chartier (2002), assumimos as fontes como dispositivos, em que reconhecemos as inventividades e os interesses dos articulistas ao produzirem os debates em circulação nos periódicos, assimilados por realidades representadas e instituídas. Mobilizamos ainda o conceito de apropriações (CERTEAU, 2002), que constituem formas diferentes de interpretações que dialogam, todo o tempo, com as práticas produtoras de ordenamento, no caso, os projetos de formação humana da eugenia e do higienismo encarnados e postos às leituras nos impressos, oferecendo os fundamentos para o ensino da EF.

Baseados em Carvalho (2006), consideramos a intrínseca relação entre o texto escrito e as formas pelas quais ele chega ao leitor, analisando como os impressos se configuram em produtos de estratégias editoriais de difusão e conformação dos saberes pedagógicos. Os dispositivos de leitura utilizados pelos editores e articulistas foram compreendidos como recursos didáticos, materializando as normas pedagógicas veiculadas pela imprensa periódica de ensino e de técnicas da Educação Física (1932-1960), fonte desta pesquisa.

\footnotetext{
${ }^{4}$ Esses estudos são oriundos do Projeto "Da imprensa periódica de ensino e de técnicas da Educação Física: trajetórias de prescrições pedagógicas (1932-1960)", que investiga como os objetivos, as metodologias, os detalhamentos técnicos, os conteúdos de ensino e a avaliação eram sistematizados nos periódicos. 
A justificativa para a periodização do estudo apresenta motivos internos e externos ao objeto. Internamente, o ano de 1932 refere-se à publicação dos primeiros números das revistas que contribuíam com a orientação da prática e com a formação dos profissionais que atuariam nas instituições escolares. São elas: a REF e a REPHy. Os motivos externos estão associados ao ano de término da imprensa periódica de ensino e de técnicas, 1960, uma vez que, cumprindo os seus propósitos, acabou por fenecer, "[...] faltando encontrar o seu lugar no século XXI" (FERREIRA NETO, 2005, p. 776).

Fundamentados nessas especificidades, baseamo-nos no mapeamento de Cassani (2018), em um total de 1.783 matérias publicadas na REF (1932-1960), REPHy (1932-1945), Boletim de Educação Física - BEF - (1941-1958), Revista Brasileira de Educação Física - RBEF - (1944-1952) e Arquivos da Escola Nacional de Educação Física - AENEFD - (1945-1966).

As matérias foram selecionadas pela leitura prévia dos títulos que remetiam a orientações para o ensino da EF, presentes na versão escrita do "Catálogo de Periódicos de Educação Física e Esporte” (FERREIRA NETO et al., 2002). Nesse momento, não buscamos terminologias específicas nos títulos, selecionando aqueles com um conteúdo que aproximasse a orientação didático-pedagógica ao professor. No processo de aproximação e registro fotográfico das fontes, também lemos o corpus textual de todas as matérias. Esse procedimento foi importante para selecionarmos as fontes que estavam sem identificação de títulos, autoria e/ou sem descrições textuais, escolhendo as matérias por seu conteúdo e forma.

Ao considerarmos o objetivo desta pesquisa, analisamos a REF e a REPHy. Em ambas, encontramos matérias que ofereciam as bases para a EF fundamentadas nas Ciências Biológicas, dentre elas, a eugenia e o higienismo. Os 88 artigos mapeados estão assim organizados: 17 na REF (19\%) e 53 na REPHy $(60 \%)$. Selecionamos ainda as publicações que apresentavam possibilidades didáticopedagógicas ao professor. As 651 matérias estão dessa forma distribuídas: 213 na REF (33\%) e 352 na REPHy (54\%). Utilizamos como critério de seleção dos dois periódicos aqueles que concentram o maior número de matérias referentes ao objeto desta pesquisa. Quando consideramos o número de matérias sobre as Ciências Biológicas (88) e as possibilidades didático-pedagógicas (651), identificamos: 230 na REF (31\%) e 405 na REPHy (55\%), totalizando 635. As fontes foram mapeadas na biblioteca do Instituto de Pesquisa em Educação e Educação Física (Proteoria), situado na Universidade Federal do Espírito Santo (Ufes), que possui em seu acervo: 92 números originais da REF; e 85 da REPhy, fotocopiados.

Elaboramos um banco de dados no Microsoft Excel para cada revista, contendo: ano de publicação; número; página da matéria; sessão do índice/sumário; autores; título; descrição do conteúdo; referenciais teóricos utilizados. Posteriormente, criamos um banco de dados para cada periódico no software IBM ${ }^{\circledR}$ SPSS ${ }$ Statistics - Version 22, atribuindo variáveis para essas informações, a fim de procedermos aos cruzamentos entre elas.

O uso desse programa como instrumento para organização das fontes possibilitou uma visão ampliada do objeto, visto que, diante de um número expressivo de artigos e de uma periodização de vinte e nove anos, foi preciso estabelecer os cruzamentos entre os dados. Tal procedimento ajudou na localização e no manuseio do corpus documental, favorecendo a compreensão da forma e do conteúdo das fontes.

Referenciamo-nos na análise crítico-documental de Bloch (2001), porque ela nos permite ler o que está presente ou ausente nos periódicos, afinal, “[...] os textos ou os documentos, mesmo os aparentemente mais claros e mais complacentes, não falam senão quando sabemos interrogá-los" (p.79). Nesse processo, os impressos foram compreendidos como artefatos dotados de intencionalidades, produzidos por indivíduos ou grupos que contribuíram com a inserção e consolidação da EF nos currículos escolares.

A leitura na íntegra de todas as matérias permitiu-nos categorizar as fontes em dois eixos principais, criados a posteriori. São eles: apropriações teóricas dos princípios eugênicos e higiênicos; e a sua materialização em prescrições didático-pedagógicas. 


\section{APROPRIAÇÕES TEÓRICAS SOBRE A REGENERAÇÃO DA RAÇA E O FORTALECIMENTO DA ROBUSTEZ}

Iniciativas em publicar orientações baseadas na ideia de melhoramento da raça humana podem ser vistas na "Revista de Ensino" (1902-1918), chancelada pela Associação Beneficente do Professorado Público de São Paulo. As discussões em circulação na revista indicavam uma decadência física e moral do brasileiro, pois, com o desenvolvimento da instrução no País, passaram a ser privilegiadas as "tarefas mentais" em detrimento dos exercícios físicos. Para resolver o problema, os articulistas anunciavam a formação do "homem de ação" e "mais apto à luta" como aquela que regeneraria e equilibraria a vida intelectual, orgânica e moral (GUALTIERI, 2008).

Nos impressos aqui analisados, as orientações em prol da saúde da população brasileira tinham como eixo central o papel da EF nesse processo. A REF, considerada o veículo de propagação dos princípios pedagógicos do Exército, via-se "responsável" por promover a nacionalização no País, comunicando e buscando convencer os leitores sobre a importância da "[...] saúde [como] perfeito equilíbrio funcional e [...] da alegria [como] renovação racial" (PINHEIRO, 1932a, p. 1). Para cumprir com a missão de "esculpir" a raça brasileira (PINHEIRO, 1932b, p. 1), o seu corpo editorial fez uso de um dispositivo que permitiu a identificação, em seu primeiro número, do projeto de formação humana sobre o qual estava consolidado. Ao utilizarem o verso da capa para publicar apenas a sentença " $\mathrm{O}$ Brasil precisa do nosso esforço para a nacionalisação definitiva" (PINTO, 1932, s. p.), os editores estrategicamente fizeram uso de um espaço de destaque no impresso, oferecendo pistas do conteúdo a ser encontrado em suas páginas e das pessoas que ali circulariam, formadoras de opinião.

Referimo-nos a Edgar Roquette-Pinto (1884-1954), autor da frase supracitada, membro do movimento eugenista brasileiro, pesquisador nas áreas de Antropologia Física e Etnografia no Museu Nacional e autor dos livros "Ensaios de Antropologia brasiliana" e "As leis da eugenia" (SOUZA, 2016). Os lugares institucionais ocupados pelo articulista sugerem-nos que a sua ideia de nacionalização estava associada à eugenia, ciência que auxiliaria “[...] no processo de melhoramento biológico da humanidade, [...] [trazendo] ferramentas importantes para pensar o funcionamento da herança genética nas 'raças humanas"' (SOUZA, 2016, p 97).

Elaborada pelo inglês Francis Galton (1822-1911), a eugenia constituía-se como a ciência que lidava com todas as influências cujo fim seria a melhoria das qualidades inatas de uma "raça", desenvolvendo-as ao máximo proveito. Em sua obra Essays in Eugenics (1909), o autor defendia a ideia de os indivíduos progredirem de tal modo que se tornassem "úteis" à sociedade e contribuíssem para as próximas gerações. Alicerçadas na educação, as práticas eugênicas trariam equilíbrio entre saúde, energia, habilidade e consistência de propósito, servindo para uma vida pesssoal, social e política "menos tola e fútil".

No Brasil, essas teorias ofereceram suporte para o debate em torno da análise dos mecanismos de transmissão de características físicas, habilidades e talentos intelectuais entre as gerações. Por meio dos instrumentos da Matemática, da Biologia e da Estatística, os estudos fomentavam a propagação dos melhores caracteres humanos, buscando impedir a reprodução daqueles considerados degenerativos (DEL CONT, 2008). Para alcance de seus objetivos, vimos em Sousa (2016) que esses projetos de intervenção eugênica poderiam ter natureza positiva ou negativa. Positivamente, priorizavam-se medidas educativas, aconselhamento eugênico, incentivo ao casamento e à procriação entre indivíduos considerados saudáveis e inteligentes, tal como proposto por Galton (1909); negativamente, impunham-se o controle matrimonial e a esterilização racial, realizada pelos exames pré-nupciais. Essas ações baseavam-se em uma rígida seleção de caracteres, servindo como uma ferramenta de segregação entre as pessoas, de eliminação daquelas consideradas indesejáveis e de privação do casamento e prole dos "degenerados".

$\mathrm{Na}$ REF, as teorias de Galton foram apropriadas por Branco (1933a, p. 19), articulista que defendia a eliminação de "[...] fatôres que [impediam] a realização soberba da saúde e felicidade gerais e conseqüente longevidade de nossos semelhantes". Por meio do estabelecimento de regras formadoras de uma prole sadia de "corpo e de espírito", ele reconhecia a importância de "[...] prosélitos apaixonados [pelos princípios galtonianos a] [...] lhe emprestarem suas luzes para tornar o ideal eugênico uma parte do sistema de educação". Em sua afirmativa, sugeria o uso dos princípios 
eugênicos no campo educacional, sob uma concepção mais formativa e positiva, do que pela erradicação (grifo nosso).

Paradoxalmente, o articulista também assumia a eugenia em sua dimensão negativa, ao acenar para a necessidade de acrescentar o número de homens reconhecidos normais, de reduzir os subnormais e os geneticamente inferiores, a fim de "[...] controlar os casamentos, evitando o matrimônio entre tarados e degenerados" (1933a, p. 19). Branco (1933a, 1942) explanou ser imperativa a apropriação do debate proposto por Renato Kehl, ${ }^{5}$ por ele identificado como o apóstolo de Galton no Brasil, afinal, suas ideias contribuiriam para o aperfeiçoamento racial das futuras gerações e a "[...] esterilisação nos indivíduos epilepticos, hemofílhicos, coreicos e outros" (BRANCO, 1942, p. 45), o que também implicaria práticas eugênicas negativas.

Cunha (1935), no mesmo periódico, atribuiu à EF o papel de auxiliar nesse processo, purificando o homem por meio da dosagem de exercícios e dando-lhe as condições para gerar "[...] filhos saudáveis, vigorosos, inteligentes, capazes de intensificar o trabalho físico e moral da raça" (p. 6). Para o articulista, os projetos de intervenção eugênica eram compreendidos e apropriados de maneiras diversas, não existindo homogeneidade em relação ao que seria desenvolvido no Brasil:

\begin{abstract}
A ação positiva da eugenia manifesta-se [...] nas uniões sexuais, a integrar todos os elementos que assegurem uma excelente procriação [...]. Considerando a ação negativa da doutrina, deparamos com motivos de oposição e malquerença erguidos contra ela [...]. Um dos aspectos dessa ação negativa é o que se refere a anormais de todas as classes, para impedir que esses influam sôbre a geração e transmitam as taras à descendência (CUNHA, 1935, p. 7).
\end{abstract}

A concordância de Cunha (1935) em relação à possível associação entre as medidas eugênicas positivas e negativas evidenciaria, tal como visto em Branco (1933a, 1942), inconsistência teórica e até equívocos referentes ao diálogo que esses articulistas estabeleceram com a eugenia. No entanto, ao centralizarmos as nossas análises nas apropriações das teorias e nos processos de difusão e conformação dos impressos a esses saberes, deslocamos o nosso olhar dessas contradições internas, para considerar as intencionalidades com as quais os periódicos eram produzidos, conforme orienta Carvalho (2001, 2006).

Em um primeiro momento, é preciso explicitar que, embora Kehl tenha sido identificado por Branco (1933a) como o "representante" das ideias de Galton no Brasil, o diálogo com Souza (2016) permite-nos inferir que as suas proposições, de natureza negativa, não coadunavam com as de Galton, caracterizadas por serem positivas.

Sob esse aspecto, Galton (1909) defendia práticas eugênicas fundamentadas no estudo e na disseminação das leis da hereditariedade, tornando possível a definição da proximidade dos graus de parentesco, taxas de nascimentos e mortes. Esses dados permitiriam: a "[...] investigação histórica sobre as taxas com as quais as várias classes da sociedade (compreendidas de acordo com a sua utilidade cívica) contribuiriam para a [formação da] população" (p. 39); e a análise das circunstâncias em que famílias numerosas e consideradas bem-sucedidas originariam com mais frequência as condições da eugenia. Em suas proposições, não há indicação de medidas que visam à erradicação, além disso, mesmo em relação ao casamento, o autor defendeu que uniões inadequadas fossem banidas, ao contrário da ideia de eliminação ou esterilização dos indivíduos.

As apropriações dos articulistas às teorias de Kehl e Galton evidenciam as estratégias editoriais utilizadas pela REF, com o objetivo de consolidar o Exército como instituição incumbida do aperfeiçoamento da raça humana. Mesmo antagônico, o diálogo com os princípios positivos e negativos da eugenia reforçava o papel assumido pelo Exército em inibir os efeitos da "miscigenação racial" às futuras gerações, conferindo-lhe a responsabilidade de solucionar os "problemas" brasileiros, fazendo avançar o País. Publicar as teorias de Kehl e Galton significava convencer os leitores sobre os diferentes estudos que preparavam o Exército em sua missão de formar aqueles que "hasteariam" a

\footnotetext{
${ }^{5}$ Kehl foi editor do "Boletim de eugenia” (principal periódico de divulgação desses princípios no Brasil), autor das "Lições de eugenia" e um dos fundadores da Sociedade Eugênica de São Paulo e da Comissão Central Brasileira de Eugenia (criada na década de 1930, com o intuito de colaborar com o governo brasileiro em relação às políticas eugênicas). Educação em Revista|Belo Horizonte|v.36|e218568|2020
} 
bandeira da eugenia no Brasil, "[...] para a honra do nosso povo, gloria da nossa Pátria e benefício da Humanidade” (BRANCO, 1933a, p. 19).

Os princípios da eugenia positiva e negativa foram veiculados concomitantemente na REF, sem que um silenciasse o outro, assim como ocorreu no cenário educacional mais macro, em que diferentes projetos eugênicos circularam no Brasil (SOUZA, 2016). No entanto, pelo fato de as práticas direcionadas para a profilaxia terem sido melhor aceitas pelos brasileiros (SOUZA, 2016), é possível que a circulação dos princípios negativos na REF não implicasse intervenções dessa natureza, tratandose de estratégias editoriais. Ao se apropriarem de teorias elaboradas por pessoas conhecidas na política brasileira, como Renato Kehl, os articulistas buscavam o reconhecimento de civis e de militares, no que se refere ao "importante" papel a ser desempenhado por eles no âmbito da educação. ${ }^{6}$

Por outro lado, a veiculação dos princípios eugênicos positivos favoreceria a ideia de desenvolvimento da nação brasileira, por meio de intervenções na área da saúde e da educação. Nesse caso, a inserção e o fortalecimento da EF na escolarização contribuiriam para que esse projeto de formação humana se consolidasse, pois somente pela aplicação de exercícios seria possível o melhoramento progressivo da "espécie", em seu aperfeiçoamento físico, psíquico e moral.

Embora antagônicas, as diferentes apropriações dos princípios eugênicos, na REF, demonstravam o cenário de "entusiasmo à doutrina" por parte de médicos, professores e legisladores que, na escola ou na caserna, defendiam a causa da EF (BRANCO, 1942). No âmbito das escolas primárias, dos ginásios, das escolas normais e do ensino superior, impunha-se a instrução de conhecimentos da Biologia humana, hereditariedade e eugenia (A EUGENIA, 1933). Em um contexto nacional, editores viam-se impulsionados a publicar livros e revistas, assim como os médicos e educadores se motivavam a realizar conferências, veiculando os ideais de aperfeiçoamento e apuro do homem brasileiro (CUNHA, 1935).

Iniciativas como essas foram materializadas em impressos chancelados por órgãos do Governo, que reuniam orientações aos professores e relatórios dedicados ao debate, como o Ministério da Educação e Saúde Pública (veiculado no Rio de Janeiro na década de 1930) e o Boletim de Educação e Saúde (chancelado pelo Estado da Bahia no início da década de 1940). Identificamos, ainda, impressos que, direcionados a causas específicas, também discutiam o assunto, como a revista Hierarchia (focalizada em estudos políticos e na inserção religiosa nas escolas públicas, editada entre 1931 e 1932), que propunha o debate sobre a educação higiênica e eugênica, pela figura de Belisario Penna. ${ }^{7}$

As correspondências entre Arthur Ramos, Octávio Domingues e Renato Kehl ${ }^{8}$ também demonstram a veiculação de suas ideias sobre mestiçagem, hereditariedade, eugenia e higiene mental: em suportes impressos (Revista O Brasil e Boletim de Eugenia); e em apresentações em Cursos e Congressos (Higiene Mental do Escolar, 1943; Congresso de Higiêne da Raça, 1943; $1^{\circ}$ Congresso Interamericano de Medicina, 1946), o que sugere o nível de abrangência pretendido para o debate em torno da eugenia, mas também da higiene no Brasil.

Os achados referentes aos Congressos oferecem-nos pistas de que as discussões sobre o tema, no País, estavam inseridas em um movimento mais amplo de produção e troca de ideias entre os países da América Latina. Captamos esse mesmo cenário na EF, inicialmente pelo uso da REPHy como espaço de propaganda e venda de revistas argentinas com escopo voltado para o melhoramento da raça: Viva cien años e a Revista Cultura Sexual e Física da Argentina. Além de indicar os locais para

\footnotetext{
${ }^{6}$ Cassani (2018) discute os tensionamentos entre o Exército e a Associação Brasileira de Educação (ABE), no ano de 1932. Os embates eram provocados, principalmente, pelas indagações da ABE em relação à futura atuação de militares nas escolas brasileiras.

${ }^{7}$ Conforme Hemeroteca Digital da Biblioteca Nacional, onde constam digitalizados os referidos impressos.

${ }^{8}$ Arthur Ramos foi fundador e chefe do Serviço de Higiene Mental do Departamento de Educação do Rio de Janeiro (1934-1939), catedrático de Antropologia e Etnologia da Universidade do Brasil e chefe do Departamento de Ciências Sociais da UNESCO (1949). Já Octávio Domingues era geneticista, autor do livro "A hereditariedade em face da Educação" (1929) e integrante da Sociedade Científica Comissão Central Brasileira de Eugenia (em 1931) e do impresso Boletim de Eugenia (em 1932), ambos coordenados por Kehl. As correspondências encontram-se no Acervo Digital da Biblioteca Nacional.
} 
venda, a revista colocava em circulação matérias oriundas especialmente da Viva cien años, o que sinaliza o alinhamento de ambos os impressos com esses projetos formativos.

Em um contexto no qual a apropriação das teorias e das medidas eugênicas significava o progresso científico, educacional e político almejado pelos países, parece-nos profícua a ideia de que esses projetos de formação se expandissem do suporte impresso para a organização de Congressos. Dentre eles, sinalizamos os Congressos Pan-Anamericanos de Educação Física, que encontraram, em Holanda Loyolla, um dos seus defensores. Conforme o articulista, esses encontros aproximavam os "expoentes" da América Latina, confrontando as suas teorias, discutindo princípios e firmando uma doutrina nos países participantes do Congresso, "[...][sobre] o bem estar do indivíduo e a eugenia das raças, para o melhoramento das condições organicas dos homens" (LOYOLLA, 1941, p. 9, grifo nosso).

Nesse cenário, cabia ao Estado a publicação de manuais cujo objetivo era vulgarizar os princípios eugênicos e defender as futuras gerações (A EUGENIA, 1933). Ante essa prerrogativa, a EsEFEx encontrou na REF o meio pelo qual fazia circular os estudos realizados na própria escola, bem como em outras instituições, com o propósito de se firmar como a responsável pelo aprimoramento racial no Brasil. Na Figura 1, vimos como essas iniciativas foram materializadas:

Figura 1 - Raios infravermelhos associados aos raios ultravioleta

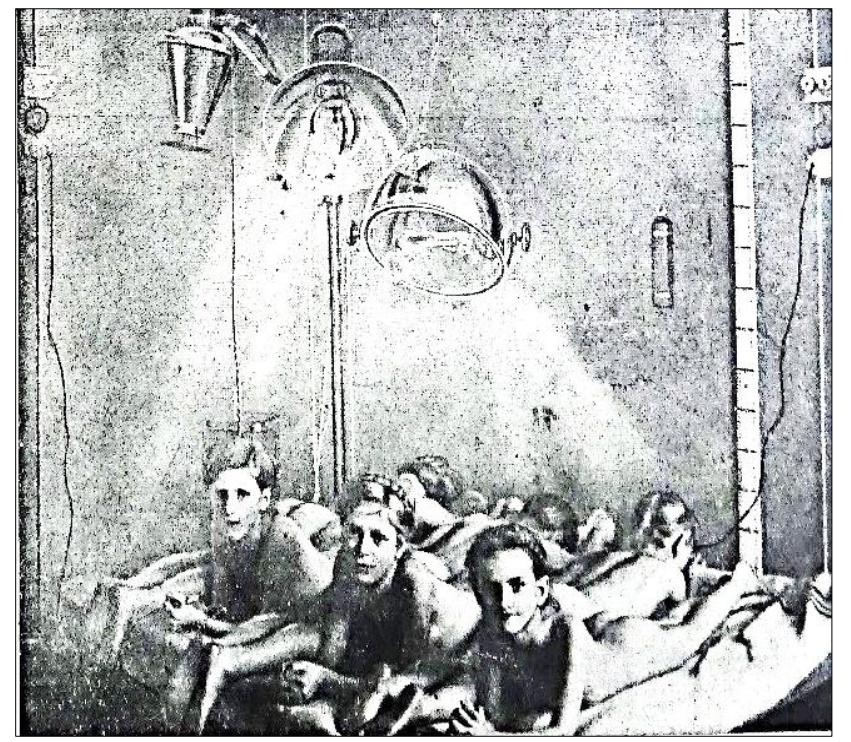

Legenda: "Ilustramos estas notas com algumas fotografias, tiradas nas principais clínicas alemãs, onde nós podemos constatar o emprêgo associado do infra-vermelho ao ultravioleta, máxime na terapêutica infantil” (p.27).

Fonte: Branco (1933b).

$\mathrm{Na}$ matéria, Branco (1933b) explicou os procedimentos a serem adotados pelos laboratórios para aplicar e associar os raios infravermelhos e ultravioletas em crianças. Essas ações buscavam reduzir os índices de mortalidade infantil, favorecendo a saúde das "[...] crianças do Rio de Janeiro que, sabemos, é uma das Capitais do mundo onde é maior o número de vítimas nas primeiras idades" (p. 27). A circulação de matérias com essas intervenções na imprensa periódica de ensino e de técnicas evidencia que determinadas práticas para fins eugênicos eram direcionadas àqueles com formação em Medicina, e, aos profissionais que atuavam com a EF, caberia divulgá-las entre os alunos.

Em um contexto mais amplo, Stephanou (2005) explicita que, no início da década de 1930, os "discursos" médicos voltavam-se para a "necessária" articulação entre a educação e a saúde, compreendendo-a como a solução para os problemas nacionais. Essas iniciativas implicaram uma intensa atuação desses profissionais nos processos educativos, ocupando-se de temas relacionados com a orientação dos conteúdos e objetos de ensino, dos procedimentos metodológicos, da avaliação e da 
salubridade das instituições. O êxito desse projeto de assistência médico-escolar dependeria das práticas colaborativas dos docentes, o que levaria os médicos a "[...] [envidarem] esforços no sentido de conquistar e preparar os professores para uma ação conjunta" (STEPHANOU, 2005, p. 159).

O diálogo estabelecido com a autora oferece-nos indícios de que matérias como as de Branco (1933b) eram direcionadas para a atuação profissional dos médicos e tinham a finalidade de orientar as suas intervenções. Ao mesmo tempo, elas visavam contribuir para a formação docente em $\mathrm{EF}$, buscando convencer o professorado sobre o importante trabalho realizado entre ambos os profissionais. As fontes sugerem que, à época, não existia uma delimitação específica de quem deveria aplicar as sessões de exercícios físicos na escola, com intervenções compartilhadas entre médicos e professores, para fins eugênicos.

Mesmo com todos os investimentos feitos para vulgarizar os princípios da eugenia, captamos nos impressos as "dificuldades" encontradas pela doutrina eugênica em estabelecer regras práticas e seguras que a conduzissem a resultados "confiáveis" no Brasil. Essas fragilidades levaram os intelectuais à incorporação de ações de natureza preventiva, profilática e de "higiene racial", cujo propósito era criar hábitos anteriores à própria intervenção proposta pela eugenia (CUNHA, 1935).

Algumas pistas que contribuíram para a (re)significação desse projeto formativo se referem à própria conjuntura social do País que, em decorrência do êxodo rural, apresentava um cenário de falta de asseio em bairros populares, com famílias numerosas e alimentação insuficiente (AZEVEDO, 1937a). Era necessário o estudo das condições de vida das cidades modernas, com teorizações mais eficazes para a sociedade do que aquelas pensadas para uma população "ideal" - almejada pelos princípios eugênicos. Isso também incluía compreender o papel social a ser desempenhado pela EF, pois, diante das demandas da vida moderna, ela seria capaz de derivar atitudes higiênicas sociais e moralizadoras para a sociedade (AZEVEDO, 1937a).

O debate proposto por Azevedo, em circulação na REPHy, também nos oferece as bases para compreender como o perfil editorial do impresso estava conectado com o pensamento do articulista sobre a EF. Ao nos debruçarmos sobre o sumário da REPHy, identificamos a temática "doutrina", que veiculava um conjunto de artigos com pressupostos teóricos para a área. Dentre as suas seções, há: Educação, História, Hygiene, Antinoüs, Filosofia da Educação e Educação Física. Essas terminologias anunciavam a perspectiva que fundamentava o projeto editorial da REPHy, alicerçado em diferentes áreas do conhecimento, com destaque para a obra Antinoüs, de Fernando de Azevedo - a única que se constituiu como seção dentro da revista. ${ }^{9}$ Nela, foram veiculados debates já publicados no livro do autor, ocupando sempre as primeiras páginas do impresso. Embora tenhamos mapeado outros cinco artigos publicados na seção Hygiene, compreendemos que as discussões elaboradas por Azevedo $(1936,1938)$ são representativas das problemáticas abordadas nesta pesquisa, motivo pelo qual enfatizamos as suas ideias. ${ }^{10}$

Em seus debates sobre as contribuições da $\mathrm{EF}$ ao desenvolvimento de atitudes higiênicas, Azevedo $(1936,1938)$ referia-se à necessidade de aprimoramento humano pela mútua dependência do vigor físico, da beleza e da elegância, base da verdadeira atlética helênica. A EF seria ensinada sob princípios científicos e plásticos, em que a Biologia e a Arte cumpririam papéis semelhantes na criação de "tipos humanos perfeitos". Ambas fundamentavam a ginástica, os jogos e os exercícios naturais. Ambas serviam ao corpo e ao espírito, a fim de que o homem alcançasse o equilíbrio somato-psíquico. Beleza, saúde, lucidez da inteligência, harmonia e nobreza no porte humano constituíam-se como o grande propósito da educação helênica, em um processo no qual o vigor físico e a contemplação do belo pela linguagem artística eram indissociáveis. As apropriações de Azevedo $(1936,1938)$ ao projeto de formação humana grega anunciavam, para o contexto brasileiro, exercícios físicos sem excessos, por

\footnotetext{
9 “Antinoüs: Estudo da Cultura Athletica”, publicada inicialmente em 1919 e incorporada à obra "Da Educação Física: o que ela é, o que tem sido e o que deveria ser", que possui três edições (1916, 1920, 1960). Neste artigo, dialogaremos com a edição de 1960.

10 Os outros três artigos discutiam sobre a higiene, considerando os seguintes aspectos: a relação com as práticas recreativas (A RECREAÇÃO, 1938); o seu desenvolvimento nas escolas da Suécia (DECÁGOLO, 1938); e os princípios para a formação do brasileiro (AUSTREGÉSILO, 1938). 
meio dos quais os desenvolvimentos do corpo, da mente e do espírito compreendiam ações voltadas à saúde, à beleza e à inteligência, pois

A saúde é o bem estar de todos os órgãos internos [...]. A beleza [...] é o desenvolvimento completo do ser humano, harmonia das proporções [...]. A força é a faculdade de produzir trabalho, a força muscular, a resistência às fadigas e às doenças. Aquisição de todo gênero de exercícios naturais e utilitários (AZEVEDO, 1938, p. 1).

Para Azevedo (1936, 1938), a construção de uma raça vigorosa estava fundamentada nos saberes da Filosofia, pois eles aperfeiçoariam a personalidade humana como valor insubstituível. ${ }^{11}$ Pela prática sistematizada e racional da $\mathrm{EF}$, os indivíduos desenvolveriam qualidades de iniciativa que, segundo apropriação de Wood e Cassidy (1934, p. 17), configuravam-se como "[...] único meio de evitar o declínio moral e físico individual e, por conseguinte, coletivo". Nesse contexto, é preciso compreender que a noção defendida por Azevedo sobre o aprimoramento do indivíduo visava a formação de uma nação sadia, defendida tanto pelos ideais eugenistas como higienistas.

Sob os preceitos da eugenia, o articulista afirmava que a regeneração física e moral do brasileiro seria fruto do melhoramento do seu organismo e da qualidade de sua educação, confirmando a importância de implementação de um projeto educacional que contribuísse para o apuro físico, intelectual e moral dos indivíduos (AZEVEDO, 1960). Por outro lado, tendo em vista a sua aproximação com o pensamento higienista, em circulação no Brasil entre as décadas de 1910 e 1920 , Azevedo (re)significou essas ideias eugenistas, "[...] [destacando] a interferência do meio como responsável pelos problemas do povo brasileiro [para que], mais tarde, [analisasse] as questões das populações pobres como um problema social e econômico" (LORENZ; VECHIA, 2009, p. 68).

A eugenia, para Azevedo, não se fixava mais ao conceito de desenvolvimento das qualidades físicas e mentais das gerações para impedir a degeneração racial. $O$ autor passou a compreendê-la de forma mais ampla, articulando os princípios eugenistas e higienistas, a fim de anunciar a sua perspectiva para revigoramento do povo:

[...] eugenia não é só a intervenção da profilaxia contra o meio biológico representado pela matéria viva, patogênica, na luta constante contra as moléstias [...]; nem é sòmente a engenharia sanitária, melhorando o meio físico, [...] onde incubam os miasmas, que infeccionam os povos, impedindo a fixação e aperfeiçoamento do tipo étnico pela ação higiênica, educativa e social; nem é apenas a defesa contra a perpetuação tenebrosa de taras hereditárias [...] (AZEVEDO, 1960, p. 231).

A ideia de complementaridade em relação a essas práticas implicou considerar que a eugenia, para o autor, seria um projeto de formação mais complexo, através do qual uma "nação poderosa" buscasse a:

[...] educação enérgica para a conquista da plenitude das fôrças físicas e morais, [...] por uma sábia política de educação, de defesa sanitária e de cultura atlética [da educação física, contínua e metódica], [...] que impulsione [o homem] [...] para o esplêndido tumultuar da vida intensamente vivida em pleno ar, acrisolada no ouro do sol (AZEVEDO, 1960, p. 232, grifo nosso).

As apropriações de Azevedo aos projetos eugênicos e higiênicos sugerem que, na REPHy, uma e outra circularam concomitantemente. A EF contribuiria para a constituição de uma nação forte e sadia, por meio da transmissão de caracteres adquiridos pelos exercícios, mas igualmente pelas práticas higiênicas $(1936,1937 b, 1938)$, promovendo o "[...] equilíbrio da saúde, [...] da capacidade pulmonar e índice da robustez do indivíduo (AZEVEDO, 1960, p. 234). Por compreendermos que a produção de

\footnotetext{
11 Azevedo (1960) estabeleceu articulação entre a ciência de Francis Galton com os princípios da Filosofia grega, motivo pelo qual encontramos, na análise dos artigos publicados na REPHy, a mesma apropriação - sobretudo por se tratar de textos extraídos da referida obra.
} 
teorias que orientavam o ensino da $\mathrm{EF}$ se retroalimentou nos impressos, em movimentos de continuidade e descontinuidade, é possível afirmar que há uma ideia de complementaridade entre ambos, eugenia e higienismo, formando novas teorias, como vimos em Azevedo. $\mathrm{O}$ fato de termos captado os projetos de formação que ofereciam suporte para a REF e a REPHy não significa que, na história da EF, haja linearidade em seu desenvolvimento, mas, sim, (re)apropriações de suas próprias teorias. Por esse motivo, ao analisarmos as possibilidades didático-pedagógicas, no próximo eixo, assumiremos como referência essa noção mais ampliada de eugenia.

Em ambos os periódicos, encontramos aproximações no que se refere ao compromisso de formarem um tipo "ideal sadio" para a população brasileira e de construírem uma raça forte e saudável, com base nos princípios da eugenia. No entanto, as especificidades dos perfis editoriais também implicam diferenciações no uso das teorias que ofereceram suporte para esse projeto de nação.

$\mathrm{Na}$ REF, esse movimento ocorreu pela circulação de ideias positivas e negativas, tendo em vista a "missão" assumida pelo Exército em esculpir a raça do País. As matérias ali publicadas relacionavam-se com o próprio perfil editorial do periódico, que divulgava as "colaborações" da caserna para a "grande pátria brasileira", propagando-a como um agente de aperfeiçoamento e de formação da saúde, da alma e do corpo da juventude do País (CHATEAUBRIAND, 1934). O impresso era forjado como porta-voz de articulistas que viam, nesse projeto de formação humana, o meio pelo qual seria idealizado um projeto oficial de EF no Brasil.

Como um suporte material que veicularia as ações do Exército no processo de constituição do homem brasileiro, a REF contribuiria para que a caserna cumprisse com sua "missão". Para persuadirem o público leitor, os articulistas com formação militar circularam exclusivamente nesse impresso, conferindo-lhe lugar de autoridade. Dentre aqueles analisados, há oficiais generais, como o Marechal Joaquim Marques da Cunha; oficiais com formação em Medicina, como o Primeiro-tenente e médico Pacífico Castello Branco, e o Instrutor de Higiene da EsEFEx e médico Lauro Barroso Studart.

Se considerarmos que o impresso é o veículo oficial de divulgação dos pressupostos do Exército para a EF (escolar ou não), em meios militares e civis, compreenderemos os motivos pelos quais os seus editores eram militares, dentre eles, o Primeiro-tenente João Ribeiro Pinheiro, que atuou como redator chefe de 1932 a 1933 ( $1^{\circ}$ ao $6^{\circ}$ número) e como autor de editoriais que abordavam o tema da eugenia. Concomitantemente, a apropriação das teorias elaboradas por intelectuais civis, como Francis Galton e Renato Kehl, garantiria confiabilidade, repercussão e adesão dos leitores, militares ou civis, junto ao periódico.

Especificamente na REPHy, é possível compreender como as teorias eugênicas e higiênicas estavam relacionadas com a necessidade de o impresso se constituir como referência no mercado editorial, tendo em vista a circulação de outro periódico que também se propunha a contribuir com a inserção e a consolidação da EF nos currículos escolares. Para serem reconhecidos entre os leitores civis e se moverem nos lugares institucionalizados (CERTEAU, 2002), os editores da REPHy compartilhavam com o Exército e com a REF a "missão" de construir uma raça forte e saudável. Contudo, ao mesmo tempo que estabeleciam semelhanças com a REF (comprometendo-se a formar um "ideal de brasileiro sadio"), também se diferenciavam dela, anunciando, em suas páginas, teorias que fundamentavam a concepção de formação humana integral helênica, ${ }^{12}$ em que "[...] a cultura physica [estava] de par com o aperfeiçoamento do caracter e o enriquecimento do espirito" (REPHy, 1938, p. 9).

Isso implicava a (re)significação das teorias da eugenia que, na REPHy, paulatinamente passam a dialogar com o higienismo, sobretudo por Fernando de Azevedo - cujas ideias foram inscritas e também conformaram a REPHy em sua materialidade. O esporte, os jogos e as atividades ao ar livre passaram a assumir um papel central, já que, como exercícios de "vantagem higiênica", desenvolveriam a respiração - considerado "[...] um dos mais importantes fatôres do equilíbrio da saúde" (AZEVEDO, 1960, p. 234), sem a monotonia dos métodos ginásticos.

A preocupação em elaborar e fazer circular um arcabouço teórico que constituísse as matérias subsidiárias da EF conformava ambos os periódicos como um espaço de formação de

12 Perspectiva essa que ganha força, no Brasil, pelos estudos de Azevedo. 
professores. Concomitantemente, as necessidades apresentadas pela prática pedagógica, como a distribuição dos alunos em um ensino coletivo, requeriam dessas teorias critérios científicos para orientar a atuação docente. Em uma dupla missão, caberia aos professores serem psicólogos e higienistas, com o objetivo de observar as condições físicas e psíquicas do educando, aperfeiçoando-as e corrigindo-as (AZEVEDO, 1937b).

\section{PRESCRIÇÕES DIDÁTICO-PEDAGÓGICAS PARA ORIENTAR A FORMAÇÃO E A PRÁTICA DOCENTE}

As discussões em torno dos desafios do homem frente à modernidade, à época, implicavam igualmente a publicação de matérias que contribuiriam para a formação docente, ensinando o professor a aplicar os exercícios físicos fundamentados na indissociabilidade da saúde orgânica e do equilíbrio nas emoções. Para tanto, os impressos colocaram em circulação matérias caracterizadas por prescrever a prática dos profissionais que ensinavam a EF, recomendando: os exercícios metódicos realizados ao ar livre, sob o Sol e harmônicos. Eles eram indispensáveis para o desenvolvimento das funções respiratórias, o "desafôgo" das excitações nervosas e a correção de taras e afecções (VALERIO, 1933), como observado na Figura 2:

Figura 2 - Vida ao ar livre

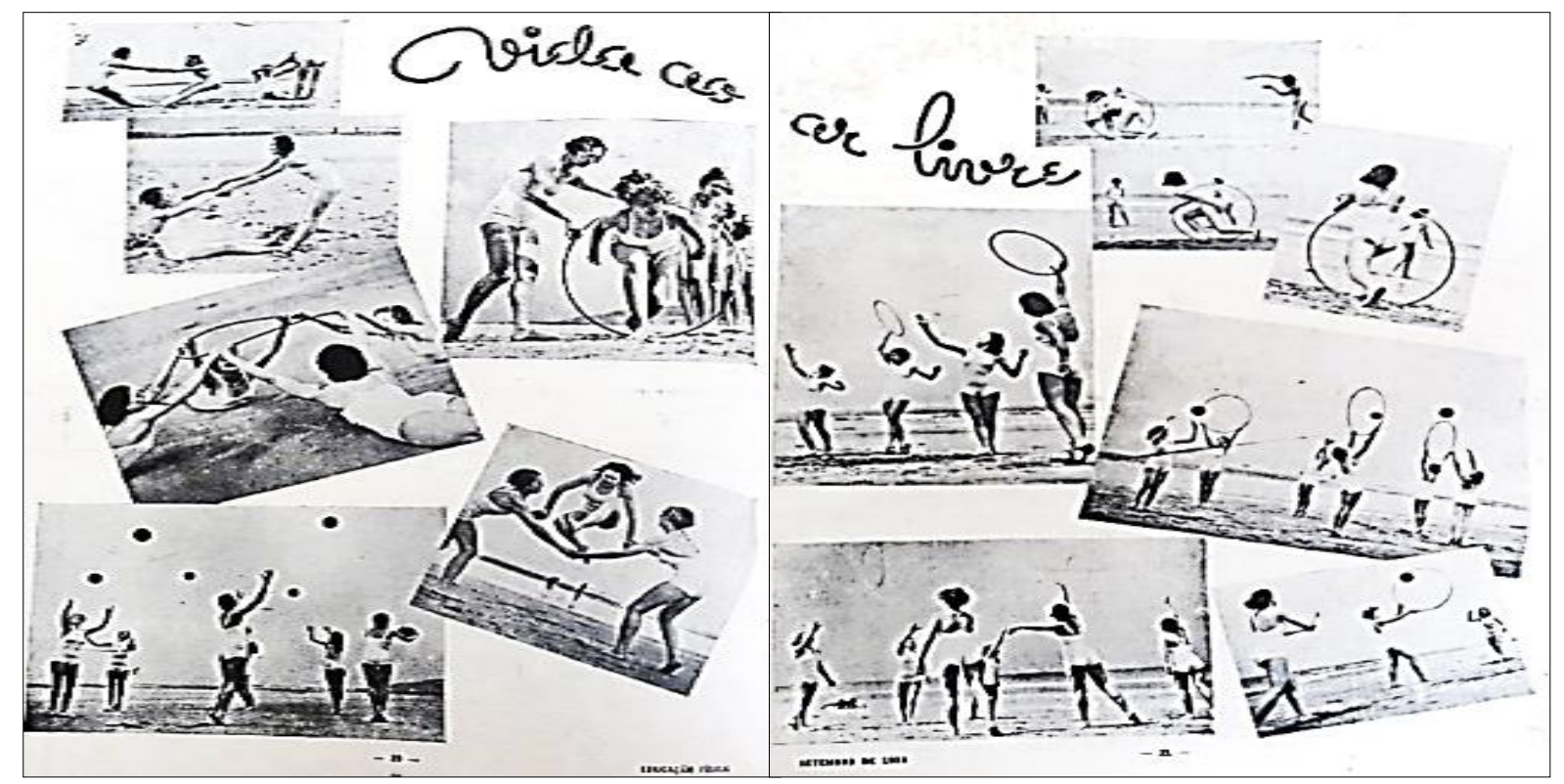

Fonte: Vida ao ar livre (1935a, p. 20-21).

A Figura 2 sugere-nos as práticas de apropriação dos editores em circulação na REF à eugenia e ao higienismo, por duas vias. Na primeira, cria-se uma seção denominada "Vida ao ar livre", que, pela sua forma, explicita os processos de conformação e editoração da revista a esses projetos de formação humana. Utiliza-se no título uma grafia de estilo manual, livre; e as fotografias são organizadas, nas páginas, tanto em uma disposição horizontal como em diagonal (para a direita e esquerda). Já a segunda via diz respeito ao conteúdo em si das matérias, mostrando para o professor como trabalhar com esses exercícios na escola. Na Figura 2, assim como em todas as matérias dessa seção, ensinava-se a ginástica feminina, com ou sem o uso de aparelhos (bolas, arcos e cordas) e em espaços como praias e jardins. Em todas elas, há fotografias de moças realizando os movimentos ginásticos, ora mostrando momentos específicos dos exercícios, como na Figura 2, ora exibindo o sequenciamento numérico e a descrição textual dos movimentos presentes nas imagens (VIDA AO AR LIVRE, 1935a, 1935b). 
A estratégia editorial de criar uma seção específica que demonstrasse os benefícios das atividades realizadas ao ar livre se fundamentava em iniciativas que promovessem "o que de mais essencial [existia] para o bom exito na vida - a saúde” (EDUCAÇÃO HYGIENICA, 1938, p. 26). Referimo-nos à publicação de revistas e folhetos cuja finalidade fosse a propagação das práticas de higiene pessoal, dentre elas, as aulas de ginástica, despertando "resultados apreciáveis" na população. O incentivo a essas publicações, como suportes que contribuiriam para a profilaxia individual e coletiva, era acompanhado de orientações em relação à delimitação no campo de atuação profissional em saúde, mas, sobretudo, evidenciava as normas pedagógicas inscritas nos periódicos. Ao anunciar que ao impresso caberia a "educação da vontade, e não indicar os meios de se tratar as doenças, serviço que [deveria] ser entregue aos medicos [...]" (EDUCAÇÃO HYGIENICA, 1938, p. 26, grifo nosso), o articulista reconhece o alcance da revista, oferecendo-nos possibilidades interpretativas em relação ao próprio conceito de educação da vontade em circulação nas fontes.

O diálogo com as pesquisas de Gondra e Silva (2014) e Oliveira (2019) auxilia-nos a compreender a complexidade de uma "educação da vontade" que conformaria a sociedade brasileira, assim como os seus processos de escolarização. As diferentes teorias que ofereceram suporte para o princípio da educação da vontade, analisadas pelos autores, evidenciam a polissemia e a complexidade do termo, motivo pelo qual nos atentamos para a sua relação com os projetos de formação humana eugenista e higienista, bem como as suas implicações para a inserção e a consolidação da EF nos currículos escolares.

Gondra e Silva (2014), ao se debruçarem na obra de Afranio Peixoto para compreenderem a sua concepção de educação da vontade, sinalizam-na como o meio pelo qual o homem conduziria "perfeitamente" os seus instintos e renunciaria a si em prol dos interesses da nação. A educação formal, pela força de sua ação, teria papel "redentor" para aprimorar a inteligência e as sensibilidades do brasileiro, afastá-lo dos vícios e das fraquezas morais, a fim de torná-lo vencedor de sua própria natureza. Para formar um homem cujo uso da inteligência o auxiliasse em suas escolhas individuais, eram necessários impressos que difundissem normativas direcionadas ao comportamento do homem, de acordo com a estratégia de promoção do bem-estar comum da nação.

Esses achados aproximam-se daqueles obtidos por Oliveira (2019), em estudo que analisou impressos espanhóis e brasileiros veiculados entre o final do século XIX e as três primeiras décadas do séc. XX. Para Oliveira (2019), a educação da vontade constituía-se em um princípio por meio do qual os sentidos do homem seriam "apaziguados", controlados, tornando-o apto para desenvolver-se intelectual e moralmente. De modo autônomo, o homem tomaria decisões, agiria e se portaria adequadamente na sociedade, a fim de civilizá-la.

Esses princípios acabavam por orientar prescrições metodológicas em meio ao debate pedagógico à época, estabelecendo parâmetros que contribuíssem para o controle das paixões humanas e seus impulsos. Seria necessária a exercitação corporal pela ginástica e pelos jogos que, fundamentada em estudos da Psicologia e da higiene, buscava "[...] o esforço, o hábito e o controle das paixões, na tentativa de produzir um indivíduo capaz de viver em liberdade [...]". As fontes analisadas por Oliveira (2019) sugerem uma "gymnastica da vontade", que consistia em realizar desde exercícios fáceis até os mais complexos, a fim de que o homem, ao se contrariar, pudesse vencer a si mesmo, mortificando-se.

A interlocução com ambas as pesquisas permite-nos um olhar mais aprofundado em relação ao cenário educacional e político em que a imprensa periódica de ensino e de técnicas foi veiculada. A aproximação com esses estudos oferece-nos pistas (GINZBURG, 1989) da circulação de diferentes projetos de formação que, antes de serem contraditórios, se complementavam. Parece-nos que a circulação dos princípios eugênicos, higiênicos e da educação da vontade nos periódicos busca atribuir à EF papel fundamental para a constituição de uma sociedade moderna e civilizada.

Sob o ponto de vista da eugenia, o ensino da EF significaria adaptações dos caracteres humanos do brasileiro, contribuindo para o melhoramento de uma raça "pura". Por sua vez, a (re)significação dessa teoria pelo higienismo dedicava-se, sobretudo, à realização dos exercícios físicos como medida preventiva, com o intuito de fazer avançar a realidade social e econômica do Brasil, aperfeiçoando e corrigindo a saúde do indivíduo. A educação da vontade configurava-se como o princípio pelo qual ambas as teorias obteriam êxito; afinal, seria ela que conformaria a ação do homem, 
incutindo-lhe hábitos que o desprendessem de práticas perniciosas - algo pretendido tanto pela eugenia como pelo higienismo. Desse modo, os periódicos assumiam papel central para a veiculação desses princípios, publicando orientações para a prática pedagógica que continham dispositivos de leitura, mostrando para o professor como ensinar as atividades realizadas ao ar livre (Figura 2) e convencendoo sobre os seus benefícios para a regeneração dos costumes e modelagem do caráter humano.

Referenciando-nos pelos estudos de Carvalho (2001, 2006), acenamos para esses dispositivos de leitura como recursos didáticos materializados nos periódicos, que evidenciavam os saberes a serem ensinados na EF e expressavam os modelos pedagógicos veiculados pelos articulistas. Ao compreendermos as suas finalidades, sinalizamos a Pedagogia "como arte de ensinar" como teorização em circulação nos impressos, por meio da qual era preciso ter a "[...] experiência de ver em execução" (CARVALHO, 2001, p. 140). A centralidade desse modelo pedagógico estava no princípio de que "sem ter visto fazer" não seria possível aprender a ensinar, ou seja, era preciso "saber-fazer". Para Carvalho (2001, p. 142), essa prática de observação do leitor modularia os seus processos de ensino e aprendizagem, "[...] guardando forte relação com uma pedagogia em que tal arte é a boa imitação de um modelo", denominada "Pedagogia prática".

Impressos dessa natureza configuravam-se como caixas de utensílios, "[...] cuja visibilidade [era] assegurada por estratégias de formação docente" (CARVALHO, 2001, p. 142). Seus usos pressupunham normas que não precisavam de explicações e, por esse motivo, eram vistas como regras culturalmente compartilhadas. Ao fornecerem bons moldes para o docente, também lhe ofereciam "coisas para usar" em suas aulas, auxiliando-o a conduzir a sua prática pedagógica. Ao captarmos o uso de dispositivos de leitura na REF e na REPHy, evidenciamos as suas aproximações com os periódicos da Educação analisados por Carvalho (2001), sinalizando que, na EF, os articulistas atuavam estrategicamente para garantir ao professor observar e copiar o que e como se faz, aprendendo como ensinar.

Nesse mesmo contexto, as prescrições didático-pedagógicas voltadas às moças também tinham especificidades pautadas nos projetos de formação eugênicos e higiênicos. Dentre os exercícios "aplicados" às mulheres, priorizavam-se as marchas, os exercícios rítmicos, os de suspensão de curta duração, o salto na corda e os lançamentos de disco e de dardo (desde que menores do que os dos homens). Fundamentados no "Réglement Géneral de Éducation Physique" (Méthode Française) Regulamento Geral de Educação Física (Método Francês) - (ESTADO MAIOR DO EXÉRCITO, 1934), ${ }^{13}$ esses exercícios eram recomendados porque evitavam golpes, pancadas e choques, e não atingiriam o órgão uterino das moças, o que seria anti-higiênico.

Por meio da EF, as alunas deveriam formar-se "mais tranquilas e educadas", com harmonia, força, saúde, graça e beleza. A elas, caberiam os exercícios voltados ao desenvolvimento de sua "bacia", haja vista o papel de procriadoras que era atribuído pela sociedade. Ao prescreverem exercícios dedicados às partes pelvianas e sacrolombares, essas matérias buscavam preparar os corpos das moças para a gestação, para que gerassem filhos fortes e saudáveis (MORGENROTH, 1940), cumprindo com os propósitos de formação eugênica e higiênica. Já a Figura 3 traz outro modelo de prescrição para o ensino da EF, também baseado no Método Francês em que os exercícios eram realizados por meio de brincadeiras historiadas:

\footnotetext{
13 Obra criada pela Escola Normal de Ginástica e de Esgrima de Joinville-Le-Pont (França), na década de 1920. Foi orientadora da Educação Física em todas as unidades do Exército, inclusive na Escola de Educação Física do Exército (CAVALCANTI, 1932). Uma análise do Método Francês pode ser vista em Bruschi (2019).
} 
Figura 3 - Lição de Educação Física

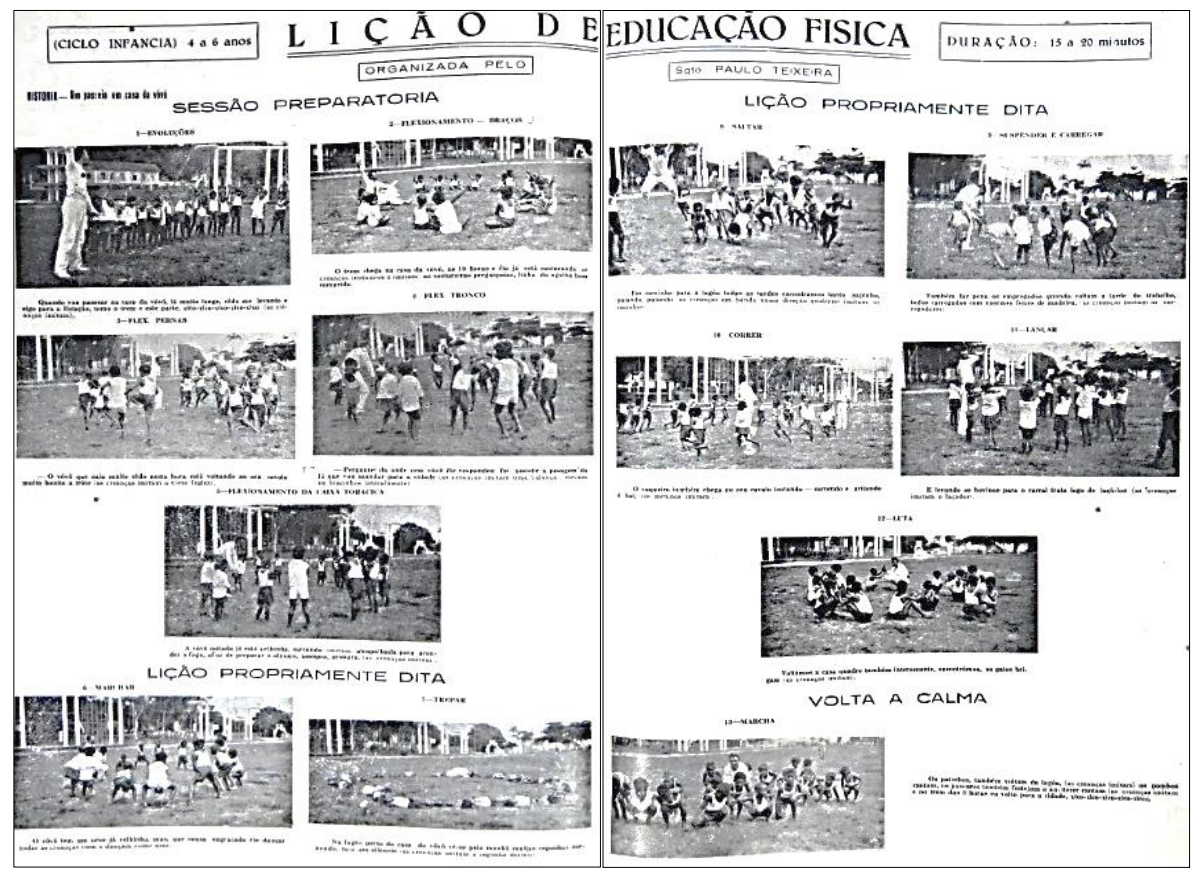

Legenda: "Um Passeio em casa da vóvó - SESSÃO PREPARATÓRIA 4 - FLEX. TRONCO - Perguntei da onde vem vôvô êle respondeu fui assistir a pesagem de lã que vou mandar para a cidade (as creanças imitam uma balança e elevam os bracinhos lateralmente)".

Fonte: Teixeira (1933, s. p.).

Essas matérias ${ }^{14}$ caracterizavam-se por oferecer roteiros para o planejamento e a condução das sessões de Educação Física na escola. Nessas matérias, intituladas pelos periódicos de lições/sessões de Educação Física, eram organizados objetivos e exercícios a serem ensinados e metodologias, assemelhando-se a modelos de planos de aula. As brincadeiras historiadas eram utilizadas com o objetivo de entusiasmar as crianças a realizarem as Lições. Nesse caso, a sistematização da Lição focalizava a educação respiratória: a sessão preparatória visava ao desenvolvimento do aparelho respiratório, com evoluções e flexionamentos da caixa torácica; e a Lição propriamente dita focalizava os exercícios pertencentes às sete famílias (marchar, trepar, saltar, suspender/carregar, correr, lançar e lutar). Cada criança deveria regular a sua respiração em um ritmo próprio, a cada esforço.

Todos esses exercícios deveriam ser naturais, pois o corpo humano funcionaria melhor se fosse exercitado com movimentos semelhantes àqueles realizados em seu cotidiano (LOTUFO, 1941). $\mathrm{Na}$ matéria, os exercícios das sete famílias eram aplicados como brincadeiras, compreendidas como movimentos realizados naturalmente pelas crianças. Para cada trecho das histórias narradas pelos instrutores, as crianças se expressariam corporalmente.

Esses exercícios de efeitos gerais poderiam ter seus resultados ainda mais ampliados "[...] si após êles [praticassem] exercícios respiratórios especiais visando a volta à calma” (TAVARES, 1935, p. 4). Nessa Lição, os exercícios de volta à calma compreendiam as marchas, orientadas por uma história: "Os patinhos voltam da lagôa (as creanças imitam), os pombos cantam, os pássaros festejam o anoitecer e cantam (as creanças imitam [...])" (TEIXEIRA, 1933, p. 5).

Ambos os artigos, presentes nas Figuras 2 e 3, mostram como a eugenia e o higienismo circulavam nos periódicos, oferecendo as bases para as prescrições de uma EF realizada ao ar livre e natural. Como projetos de formação, focalizavam a saúde física do ser humano, visando também à qualidade do seu estado de "saúde espiritual". Perante essa concepção, o bem-estar do espírito não era um meio para a "saúde física", mas um fim em si mesmo, em uma influência recíproca entre corpo e espírito.

\footnotetext{
${ }^{14}$ Lições semelhantes a essa foram veiculadas na REPHy, em um total de 28. Na REF, elas somam 27 publicações. Educação em Revista|Belo Horizonte|v.36|e218568|2020
} 
Sob os fundamentos da Ciência, a educação higiênica pretendia corrigir "[...] a fraqueza organica, [produzir] figura symetrica, [desenvolver] os músculos, [dilatar] o thorax, [augmentar] a vitalidade e a resistencia, pondo a saùde sobre um pedestal firme" (EDUCAÇÃO HYGIENICA, 1938, p. 9). A EF desenvolveria o vigor físico necessário para o equilíbrio da vida humana, a felicidade da alma, buscando a preservação da pátria e a dignidade da "espécie" (EDUCAÇÃO HYGIENICA, 1938).

Esses achados permitem-nos afirmar que as prescrições didático-pedagógicas realizadas ao ar livre, publicadas na REF e REPHy, tinham as suas bases nas teorias de Jean-Jacques Rousseau (1712-1778), para o qual a educação deveria proporcionar uma formação para a vida, por meio do contato das crianças com os animais, plantas e fenômenos físicos (coisas de modo em geral). Rousseau $(1992)^{15}$ valorizava um saber produzido pela experiência, cuja principal motivação era a curiosidade. Era essa curiosidade que levava a criança a aprender a pensar, não como um processo de fora para dentro, mas como um desenvolvimento "interno" e "natural".

Por valorizar as necessidades "espontâneas" e os processos livres de crescimento das crianças, Rousseau (1992) recomendava o seu contato direto com a natureza, a fim de potencializar as suas descobertas - tal como sugere a Figura 3. Voltados para uma educação dos sentidos, o trabalho manual, o exercício físico e a higiene tinham lugar central em suas teorias, configurando um caráter essencialmente prático da educação. $\mathrm{O}$ ensino pela experiência estimularia a criança a se unir às coisas, para que, gradativamente, desenvolvesse seu espírito e seu juízo.

O processo de análise evidencia especificidades em relação aos pressupostos teóricos que ofereceram as bases para as prescrições em circulação nos impressos da EF. Além das (re)apropriações dos princípios da eugenia e do higienismo, teorias como as de Rousseau (1992) foram mobilizadas para que a aplicação dos exercícios obtivesse os resultados esperados como medidas higiênicas. Nesse processo, as bases da Filosofia grega ${ }^{16}$ eram enfatizadas pelos articulistas, com o intuito de vulgarizar a cultura física como forma de satisfazer espírito e corpo indissociavelmente.

A publicação desses fundamentos tinha a finalidade de conferir à EF papel de importância na formação integral do homem brasileiro, o que também contribuiu para a sua inserção no "Quadro Geral da Educação". Não se falava mais em uma educação intelectual, desconsiderando uma EF. A matéria passou a ser vista articulada com o cenário educacional:

Educação Física não poderia mais ser confundida com os aspectos particulares do seu ensinamento técnico: ginástica, esportes ou jogos escolares. É um processo global, por sua natureza, inseparável do próprio conceito de educação, tomado em sua totalidade (RAMOS, 1936, p. 35).

Outras iniciativas foram materializadas pela REPHy, com o objetivo de projetar uma EF com fins higiênicos. O articulista apropria-se do parecer sobre a Instrução Primária (1882), emitido por Rui Barbosa (1849-1923), para reafirmar:

A gymnastica não é agente, materialista, mas pelo contrario, uma influencia tão moralizadora, quanto hygienica, tão imprescindivel á educação do sentimento e do espirito quanto á estabilidade da saúde e o vigor dos orgãos (EDUCAÇÃO HYGIENICA, 1938, p. 9, grifo nosso).

Sua narrativa apresenta, semelhante a Studart (1937) e Fischer (1938), os princípios para a escolarização da EF, fundamentados na indissociabilidade entre corpo, mente e espírito. Para contemplar as orientações de Rui Barbosa, o editor vê na ginástica, em especial na calistenia, uma série

\footnotetext{
15 Referimo-nos à obra "Emilio, ou da Educação", publicada em sua 1ª versão em 1762.

${ }^{16}$ Studart (1937, p. 39) ressalta que, na antiga civilização grega, os homens realizavam seus exercícios sob "[...] a influência benéfica do ar, da luz do sol [...] [em uma] concepção francamente fisiológica e higiênica, [e respiravam] em um ambiente de saúde, equilíbrio e euforia". Nota-se como a Filosofia fora apropriada e (re)significada pelos articulistas, pois ora ela se apresenta como fundamento da eugenia, ora do higienismo.
}

Educação em Revista|Belo Horizonte|v.36|e218568|2020 
de exercícios de alta importância educativa, dentre eles, os ritmados: “[...] exercicios propriamente hygienicos, que têm por fim fortalecer e desenvolver os orgãos vitaes, estimular a circulação e desenvolver e trenar os grupos de musculos do tronco [e] pernas" (EDUCAÇÃO HYGIENICA, 1938, p. 9). ${ }^{17}$

Com base nesses princípios, foram veiculados artigos com o propósito de orientar a atuação dos professores, ensinando-os a selecionar e combinar os movimentos da calistenia, com música e sequenciamento dos exercícios, conforme demonstram o Quadro 1 e as Figuras 4 e 5:

\section{Quadro 1 - Callisthenia: detalhamentos técnicos}

XIII - Posição inicial - mãos á nuca, pés separados

1. Inclinar o tronco para a esquerda

2. Repetir o movimento para a direita

XIV - Posição inicial - sentado

1. Deitar

2. Voltar á posição inicial

XV - Posição inicial - deitado, mãos ao lado do corpo

1. Levantar a perna esquerda, estendida

2. Voltar á posição inicial

XVI - Posição inicial - deitado, pernas levantadas, esquerda acima da direita; mãos

ao lado do corpo, palmas apoiadas no chão

1. Alternar a posição das pernas

2. Nota: Permanecer na posição enquanto durar o exercício

Figura 4 - Música para realização dos exercícios

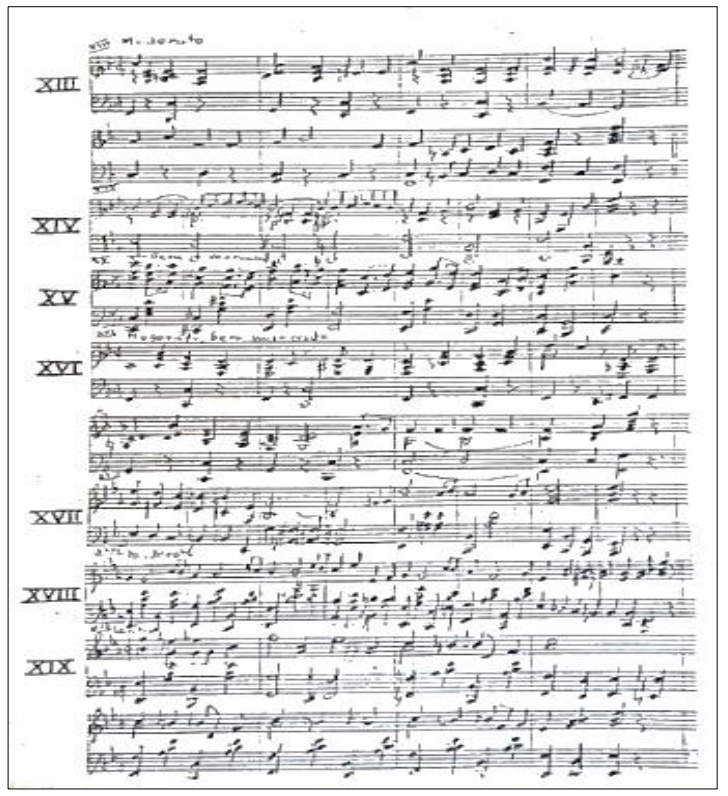

Figura 5 - Série de exercícios livres

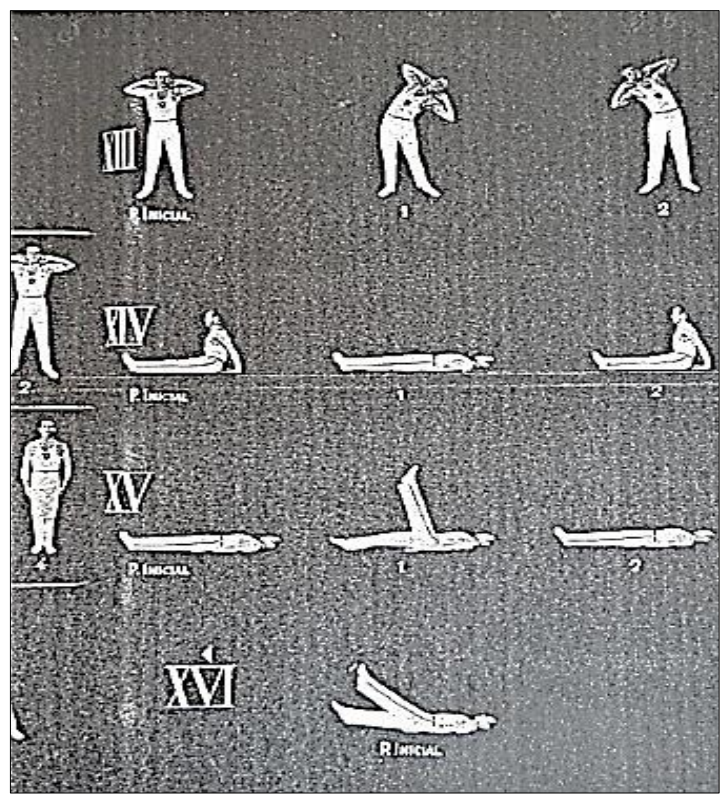

Fonte: Moraes (1932, p. 29-24).

$\mathrm{Na}$ matéria assinada por Moraes (1932), foram utilizados três recursos com a finalidade de favorecer o processo de aprendizagem do professor, oferecendo-lhe suporte para a sua atuação profissional. No Quadro 1 e nas Figuras 4 e 5, as séries de exercícios combinados, enumerados entre 13

${ }^{17}$ Entre 1932 e 1960, a REPHy veiculou 12 prescrições didático-pedagógicas para a calistenia; a REF, todavia, não publicou nenhuma. 
e 16, são ensinadas de maneira distinta: em forma de texto; por meio da partitura musical (músicas específicas para cada número, com mudanças de compasso e tonalidades); e por fotografias de uma pessoa realizando os movimentos descritos anteriormente. ${ }^{18}$

Para obter os benefícios sobre a ação mecânica dos músculos, a função orgânica e o sistema nervoso, era preciso praticar a calistenia sob os preceitos higiênicos (MORAES, 1932). Como substituta da atividade natural do homem, ela deveria ser executada em ambientes bem ventilados, perto de parques e jardins, pois "[...] os locaes confinados não são os mais aptos para exercitar os musculos nem para provocar esses intercambios orgânicos, porque, em lugar de favorecer o organismo, lhe prestaria frouxo trabalho" (WOOD, 1938, p. 54).

A análise das prescrições didático-pedagógicas acena para a apropriação dos princípios eugênicos no processo de conformação dos periódicos, justificada pela necessária elaboração de manuais artísticos e intelectuais que divulgassem os seus ideais entre a população, facilitando a sua compreensão sobre o assunto (CUNHA, 1935). Por esse motivo, o uso da linguagem escrita, musical e imagética nessas prescrições encontrou proficuidade nos periódicos da EF, pois eles ofereciam, de modo preciso e simplificado, possibilidades de intervenção profissional. ${ }^{19}$

De acordo com Cassani (2018), essas prescrições caracterizavam-se por mostrar ao professor os procedimentos necessários para conduzir as suas sessões na escola, bem como por ensinar os métodos ginásticos, os jogos, as brincadeiras, a dança e os esportes. Essas matérias tinham como finalidade levar o professor ao modo de fazer os exercícios, dando-lhe as condições para os ensinar aos alunos. Elas orientavam sobre a maneira "correta" de realizar a técnica corporal, projetando o corpo humano em diferentes momentos da realização de determinado movimento, seja por imagens, seja por texto. Com isso, prescreviam a maneira "mais eficiente" de desempenho técnico-corporal.

Como analisado por Retz (2018), as imagens presentes nas prescrições constituem-se em dispositivos de modelização da leitura (CARVALHO, 2006) e tinham a finalidade de colaborar com a formação daqueles que ensinavam a EF, fundamentados na ideia do fazer para aprender e do aprender fazendo (FERREIRA NETO, et al., 2014). Para que fossem bons executantes e tivessem condições de ensinar os exercícios, os professores deveriam observar as imagens articuladas com os textos escritos, para, posteriormente, se apropriarem corporalmente dessas prescrições. Ao fazerem parte do projeto editorial dos periódicos, as imagens também eram utilizadas com o intuito de contribuir com a escolarização da EF.

Os achados permitem-nos inferir que a elaboração de teorias, nos impressos, significou a produção de prescrições que conferissem à EF o caráter essencialmente prático. Essa constatação está vinculada à própria urgência colocada pela modernidade de requerer um homem formado para a ação. No entanto, não se tratava de uma prática pela prática, destituída de sentidos, mas, sim, articulada intrinsecamente com o intelecto e com a moral dos indivíduos. Se o brasileiro do século XIX era "[...] diminuído nas suas aspirações, atingido no seu físico, [...] abatido de ânimo e indolente, [o brasileiro dos nossos dias, do século $\mathrm{XX}]$ salta pelas praias, exercita-se nas pistas, [...] com a vida palpitando em seus movimentos" (STUDART, 1937, p. 40).

Remetemo-nos à matéria de Studart (1937) para darmos visibilidade à representação do brasileiro semelhante à do Jeca Tatu: se antes ele era símbolo daquilo que deveria ser combatido no País, paulatinamente ele se tornou a personificação daquilo que poderia dar certo no Brasil, haja vista os esforços no campo da profilaxia eugênica e higiênica em fazer aquele homem sem ânimo "[...] [vibrar] em suas ambições" (STUDART, 1937, p. 40). Essas matérias conferiam à EF o resgate do "abismo" em que o País se encontrava, em uma narrativa otimista sobre a constituição da pátria brasileira (STUDART, 1937).

\footnotetext{
${ }^{18} \mathrm{O}$ artigo é composto por 19 sequências de exercícios; todas elas apresentam: descrições textuais, músicas específicas e fotografias para melhor visualização.

${ }^{19}$ Do total de 1.783 artigos mapeados por Cassani (2018), distribuídos na REF, REPHy, BEF, RBEF e AENEFD, foram encontradas 651 publicações, caracterizadas por prescrever a prática pedagógica. Dessas, 338 apresentam dispositivos imagéticos direcionados ao ensino e à aprendizagem dos exercícios e 20 possuem composições coreográficas acompanhadas de partituras.
} 


\section{CONSIDERAÇÕES FINAIS}

O processo de interpretação das fontes evidenciou a necessidade de divulgar um rol de saberes que conferiria cientificidade à $\mathrm{EF}$, de tal modo que ela acompanhasse os avanços de diferentes áreas do conhecimento. Essas matérias buscavam convencer os professores sobre o necessário diálogo com diferentes teorias, com o intuito de fundamentar a EF no processo de escolarização.

Ao analisarmos as matérias que abordavam o papel da EF na regeneração da raça e no fortalecimento da população brasileira, sinalizamos os diferentes projetos de formação humana em circulação nos impressos e a relação dos seus perfis editoriais com o eugenismo e o higienismo. Acenamos, ainda, para as práticas de apropriação que elaboraram novas teorias, articulando ambos os projetos, especialmente por Fernando de Azevedo.

Colocar-se como suporte para auxiliar os professores na realização das sessões de EF implicou que as revistas oferecessem os meios pelos quais eles se apropriariam desses princípios, voltados para a constituição identitária nacional. Tornando esses conhecimentos acessíveis, os articulistas contribuíam com os processos formativos e com a prática profissional daqueles que aplicariam os exercícios físicos, por meio de prescrições didático-pedagógicas.

A análise do corpus documental acenou para a apropriação das teorias de Rousseau que, dentre outros autores, como Édouard Claparède (1873-1940) e John Dewey (1859-1952), lançou as bases para a difusão do pensamento da Escola Nova na Educação e EF brasileira. Fundamentado na Psicologia e na Pedagogia, esse ideário anunciava o ensino centrado nos sujeitos da aprendizagem, em uma escola de natureza prática, fornecendo os alicerces de uma EF "racional" e/ou "científica".

As discussões sobre os modelos de formação humana baseados na eugenia e no higienismo requeriam o "enquadramento" da EF, do ponto de vista científico, nos domínios da Biologia Geral. Com esse propósito, os intelectuais em circulação na imprensa periódica de ensino e de técnicas apropriaram-se de estudos da grande área da Biologia para elaborar as teorizações específicas da EF. Desse modo, anunciamos a potencialidade de pesquisas que analisem as práticas de apropriação dos articulistas a essas teorias e as de outras áreas do conhecimento, contribuindo para a inserção e a consolidação da EF nos currículos escolares.

\section{FONTES}

A EUGENIA e a constituinte. Revista de Educação Física, Rio de Janeiro, ano 2, n. 4, [s. p.], jan. 1933.

A RECREAÇÃO. Educação Física, Rio de Janeiro, n. 17, p. 9,70, abr. 1938.

AUSTREGÉSILO, A. Optimismo salutar. Educação Physica, Rio de Janeiro, n. 17, p. 8, abr. 1938.

AZEVEDO, F. Antinoüs. Educação Physica, Rio de Janeiro, n. 6, p. 13-14, set. 1936.

AZEVEDO, F. O papel do professor moderno de educação physica. Educação Physica, Rio de Janeiro, n. 8, p. 15-17, fev. 1937a.

AZEVEDO, F. O problema da hygiene social pela educação physica: medidas que o resolvem. Educação Physica, Rio de Janeiro, n. 11, p. 8-10, set. 1937b.

AZEVEDO, F. Antinoüs: padrão da educação integral. Educação Physica, Rio de Janeiro, n. 15, p. 1, fev. 1938.

BRANCO, P. C. Da eugenia. Revista de Educação Fisica, Rio de Janeiro, ano 2, n. 12, p. 19, nov. 1933a.

BRANCO, P. C. Do emprego dos raios infra-vermelhos associados aos raios ultra-violetas. Revista de Educação Fisica, Rio de Janeiro, ano 2, n. 11, p. 26-27, out. 1933b. 
BRANCO, P. C. A educação física e a eugenia. Revista de Educação Fisica, Rio de Janeiro, ano 10, n. 54, p. 45, ago. 1942.

CAVALCANTI, N. Unidade de doutrina. Revista de Educação Fisica, Rio de Janeiro, ano 1, n. 2, [s. p.], jun. 1932.

CHATEAUBRIAND, A. Dinâmica corporal. Revista de Educação Física, Rio de Janeiro, ano 3, n. 18, p. 1, dez. 1934.

CUNHA, J. M. Nos domínios da eugenia: cuidados necessários à conservação da saúde e melhoramento da raça. Revista de Educação Fisica, Rio de Janeiro, ano 4, n. 26, p. 6-7, set. 1935.

DECÁGOLO Sueco. Educação Física, Rio de Janeiro, n. 16, p. 36, mar. 1938.

EDITORIAL. Educação Physica, Rio de Janeiro, n. 4, p. 11, mar. 1934.

EDITORIAL. Educação Physica, Rio de Janeiro, n. 15, p. 9, fev. 1938.

EDUCAÇÃO HYGIENICA DO POVO. Educação Physica, Rio de Janeiro, n. 19, p. 9, jun. 1938.

ESTADO MAIOR DO EXÉRCITO. Regulamento de educação física (1 ${ }^{\mathrm{a}}$ parte). Rio de Janeiro: Biblioteca de "A Defesa Nacional", 1934.

FISCHER, L. Recompensas da saúde physica. Educação Physica, Rio de Janeiro, n. 18, p. 14-15 e 78, maio 1938.

GALTON, F. Essays in eugenics. London: The Eugenics Education Society, 1909.

LANGTON, C. V. Saúde e educação physica. Educação Physica, Rio de Janeiro, n. 15, p. 17-18 e 7071, fev. 1938.

LOTUFO, J. O valor da ginástica. Educação Fisica, Rio de Janeiro, n. 52, p. 54, mar. 1941.

LOYOLLA, H. Congressos. Educação Física, Rio de Janeiro, n. 57, p. 9, ago. 1941.

MORAES, Cyro A. Callisthenia: série de exercicios livres. Educação Physica, Rio de Janeiro, n. 2, p. 2945, dez. 1932.

PINHEIRO, J. R. O exercito e o $5^{\circ}$ congresso de educação. Revista de Educação Fisica, Rio de Janeiro, ano 1, n. 2, [s. p.], jun. 1932a.

PINHEIRO, J. R. Militarismo e educação fisica. Revista de Educação Fisica, Rio de Janeiro, ano 1, n. 1, [s. p.], maio $1932 \mathrm{~b}$.

PINTO, E. R. O Brasil precisa do... Contracapa. Revista de Educação Fisica, Rio de Janeiro, ano 1, n. 1, [s. p.], maio 1932.

RAMOS, A. A educação física elementar sob o ponto de vista da caracterologia. Revista de Educação Fisica, Rio de Janeiro, ano 4, n. 33, p. 35-36, out. 1936.

REVISTA TÉCNICA. Educação Physica, Rio de Janeiro, n. 1, [s. p.], 1932. 
SALZANO, E. Educação Física. Revista de Educação Fisica, Rio de Janeiro, ano 4, n. 24, p. 7-11, jul. 1935.

STUDART, L. B. A educação física como fator higiênico. Revista de Educação Fisica, Rio de Janeiro, ano 5, n. 37, p. 39-40, dez. 1937.

TAVARES, L. S. Educação respiratória. Revista de Educação Fisica, Rio de Janeiro, ano 4, n. 21, p. 4-5, abr. 1935.

TEIXEIRA, P. Lição de educação física. Revista de Educação Fisica, Rio de Janeiro, ano 2, n. 4, [s. p.], jan. 1933.

VALERIO, A. Educação física. Revista de Educação Fisica, Rio de Janeiro, ano 2, n. 5, [s. p.], fev. 1933.

VIDA ao ar livre. Revista de Educação Fisica, Rio de Janeiro, ano 4, n. 26, p. 20-21, out. 1935 a.

VIDA ao ar livre. Revista de Educação Fisica, Rio de Janeiro, ano 4, n. 27, p. 22-28, out. 1935b.

WOOD, A. Callistenia. Educação Physica, Rio de Janeiro, n. 21, p. 50-55, ago. 1938.

WOOD, A.; T., D.; CASSIDY, R. F. A philosophia da educação physica. Educação Physica, Rio de Janeiro, n. 4, p. 17-18, mar. 1934.

\section{REFERÊNCIAS}

AZEVEDO, F. de. Da educação física: o que ela é, o quem tem sido e o que deveria ser. São Paulo: Melhoramentos, 1960.

BLOCH, M. Apologia da história ou o ofício do historiador. Rio de Janeiro: Jorge Zahar Editor, 2001.

BRUSCHI, M. Entre a França e o Brasil: criação, circulação e apropriações do Método Francês de Educação Física (1931-1960). 2019. Tese (Doutorado em Educação Física) - Programa de PósGraduação em Educação Física, Universidade Federal do Espírito Santo, Vitória, 2019.

CARVALHO, M. M. C. de. Molde nacional e fôrma cívica: higiene, moral e trabalho no projeto da Associação Brasileira de Educação (1924-1931). Bragança Paulista, SP: Edusf, 1998.

CARVALHO, M. M. C. de. A caixa de utensílios e a biblioteca: pedagogia e práticas de leitura. In: VIDAL, D. G.; HILSDORF, M. L. S. (Org.). Brasil 500 anos: tópicas em história da educação. São Paulo: Ed. da USP, 2001. p. 137-167.

CARVALHO, M. M. C. de. Livros e revistas para professores: configuração material do impresso e circulação internacional de modelos pedagógicos. In: PINTASSILGO, J. et al. (Org.). História da escola em Portugal e no Brasil: circulação e apropriação de modelos culturais. Lisboa: Edições Colibri/ Centro de Investigação em Educação da Faculdade de Ciências da Universidade Lisboa, 2006. p. 141-175.

CASSANI, J. M. Da imprensa periódica de ensino e de técnicas aos livros didáticos da educação física: trajetórias de prescrições pedagógicas (1932-1960). 2018. Tese (Doutorado em Educação Física) Programa de Pós-Graduação em Educação Física, Universidade Federal do Espírito Santo, Vitória, 2018.

CERTEAU, M. de. A invenção do cotidiano: 1. artes de fazer. 15. ed. Petrópolis: Vozes, 2002. 
CHARTIER, A-M. Um dispositivo sem autor: cadernos e fichários na escola primária. Revista Brasileira de História da Educação, Campinas, SP, n. 3, p. 9-26, jan./jun. 2002.

CHARTIER, R. À beira da falésia: a história cultural entre certezas e inquietudes. Porto Alegre: Ed. da Universidade da UFRGS, 2002.

CLAPARÈDE, E. A educação funcional. 5. ed. São Paulo: Companhia Editora Nacional, 1958.

DEL CONT, V. Francis Galton: eugenia e hereditariedade. Scientiae Studia, São Paulo, v. 6, n. 2, p. 201-18, 2008.

FERREIRA NETO, A. Publicações periódicas de ensino, de técnicas e de magazines em educação física e esporte. In: DACOSTA, L. P. (Org.). Atlas do esporte no Brasil. Rio de Janeiro: Shape, 2005. p. 776-777.

FERREIRA NETO, A. et al. Catálogo de periódicos de educação física e esportes (1930-2000). Vitória: Proteoria, 2002.

FERREIRA NETO, A. et al. Por uma teoria da educação física brasileira na imprensa periódica de ensino, técnica e científica. Movimento, Porto Alegre, v. 20, n. 4, out./dez. 2014.

GINZBURG, C. Mitos, emblemas e sinais: morfologia e história. São Paulo: Companhia das Letras, 1989.

GÓIS JUNIOR, E. Ginástica, higiene e eugenia no projeto de nação brasileira: Rio de Janeiro, século XIX e início do século XX. Movimento, Porto Alegre, v. 19, p. 139-159, 2013.

GÓIS JUNIOR, E.; GARCIA, A. B. A eugenia em periódicos da Educação Física Brasileira (19301940). Revista da Educação física, Maringá, v. 22, p. 247-254, 2011.

GONDRA, J. Artes de civilizar: medicina, higiene e educação escolar na Corte Imperial. Rio de Janeiro: EdUERJ, 2004.

GONDRA, J.; SILVA, M. DE L. DA. Educação da inteligência, educação da vontade na escrita da história da educação brasileira (1826-1929). Cadernos de História da Educação, Uberlândia, v. 13, n. 1, p. 65-79, jan./jun. 2014.

GUALTIERI, R. M. E. Leituras de formação: raça, corpo e higiene em publicação pedagógica do início do século XX. Revista Brasileira de História da Educação, Maringá, v. 8, n. 3, p. 49-67, set./dez. 2008.

LORENZ, K. K.; VECHIA, A. Fernando de Azevedo e a questão da "raça brasileira": sua regeneração pela educação física. Cadernos de História da Educação, Uberlândia, v. 8, n. 1, p. 57-70, jan./jun. 2009.

OLIVEIRA, M. A. T. de. Educação da vontade e renovação pedagógica nos contextos espanhol e brasileiro nas décadas iniciais do século XX. Revista Brasileira de Educação, Rio de Janeiro, v. 24, e240008, 2019.

RETZ, R. P. C. Ver para fazer e aprender para ensinar: prescrições pedagógicas em imagens para a educação física (1932-1960). Dissertação (Mestrado em Educação Física) - Programa de PósGraduação em Educação Física, Universidade Federal do Espírito Santo, Vitória, 2018.

ROUSSEAU, J-J. Emílio ou da educação. Rio de Janeiro: Bertrand Brasil, 1992. 
SOUZA, V. S. A eugenia brasileira e suas conexões internacionais: uma análise a partir das controvérsias entre Renato Kehl e Edgard Roquette-Pinto, (1920-1930). História, Ciências, Saúde: Manguinhos, Rio de Janeiro, v. 23, p. 93-110, dez. 2016. Suplemento.

STEPHANOU, M. Discursos médicos e a educação sanitária na escola brasileira. In: STEPHANOU, M.; BASTOS, M. H. C. (Org.). Histórias e memórias da educação no Brasil: século XX. Petrópolis, RJ: Vozes, 2005. v. 3.

\section{AGRADECIMENTOS}

Os autores agradecem às seguintes agências de fomento pelo auxílio financeiro destinado à pesquisa: Fundação de Amparo à Pesquisa e Inovação do Espírito Santo (Fapes), Edital Universal n. 006/2014 Processo n. 67.6438.25; Coordenação de Aperfeiçoamento de Pessoal de Nível Superior (Capes); Conselho Nacional de Desenvolvimento Científico e Tecnológico (CNPq) - Edital Universal 2018, Processo n. 435195/2018-2; Bolsa Produtividade CNPq Nível 2.

Submetido: $14 / 01 / 2019$

Aprovado: 11/04/2019 